\title{
Determination of Basal Temperature and Its Relationship With Jatropha Crop in Irrigated and Non-irrigated System
}

\author{
Diogo H. M. Moraes ${ }^{1}$, Derblai Casaroli ${ }^{1}$, Adão W. P. Evangelista ${ }^{1}$, José Alves Júnior ${ }^{1}$, Rafael Battisti ${ }^{1}$ \\ $\&$ Marcio Mesquita $^{1}$ \\ ${ }^{1}$ College of Agronomy, Federal University of Goiás, Goiânia, Brazil \\ Correspondence: Diogo H. M. Moraes, College of Agronomy, Federal University of Goiás, Goiânia, Brazil. Tel: \\ 55-649-9243-3948. E-mail: diogo.slmb@gmail.com
}

Received: October 30, 2018

Accepted: November 30, 2018

Online Published: January 15, 2019

doi:10.5539/jas.v11n2p465

URL: https://doi.org/10.5539/jas.v11n2p465

\begin{abstract}
Full plant growth and development require, among others, air temperatures and water availability at levels appropriate to each crop. The effect of temperature on plant development can be represented by the thermal sum, which requires the lower basal temperature for each plant species. However, plant responses may be different when associated with different soil water contents. This work determined the lower and upper basal temperature of Jatropha curcas L. and verified the relationship between thermal sum and crop development under different water regimes, in the climatic conditions of Goiânia, GO, Brazil. We evaluated twenty-four plants cultivated at the planting density of 2,222.2 plants ha ${ }^{-1}$. Of these, twelve plants were irrigated from October 2010 to October 2012, whereas the other twelve remained unirrigated. Basal temperatures were estimated by four different methods described in the literature, in two phases of observation, maturity and total cycle. From the results, regression analysis was performed. The lower basal temperature was 4.9 and $7.2{ }^{\circ} \mathrm{C}$, and upper basal temperature was 38.8 and $36.8{ }^{\circ} \mathrm{C}$, respectively, for the maturity and total cycle stages. The accumulated thermal sum for the complete plant development of jatropha was $10,314.55 \mathrm{DD}( \pm 1574.73)$ for the non-irrigated treatment, and $9,260.67 \mathrm{DD}( \pm 735.06)$ for the irrigated treatment. The results of plant development showed good coefficient of determination in relation to the accumulated thermal sum.
\end{abstract}

Keywords: Jatropha curcas L., temperature, degree-days, growth and development

\section{Introduction}

Jatropha curcas L. is a perennial monoic species belonging to the family Euphorbiaceae, which also includes species of castor bean (Ricinus sp.), manioc (Manhiot sp.) and rubber tree (Hevea spp.). Regarding production, its main characteristic is to supply raw material for Biodiesel generation. It is considered a rustic, sunlight-demanding crop with high resistance to drought. Jatropha presents great adaptability to diverse edaphoclimatic and low soil fertility conditions (Arruda, Beltrão, De Souza, Jamil Marur, \& Severino, 2004; Freitas, Missio, Matos, Resende, \& Dias, 2011).

Pena, Evangelista, Casaroli, and Alves Júnior (2016) determined the temperature range suitable for the development of jatropha: between 15 and $28{ }^{\circ} \mathrm{C}$. Moreover, the authors observed that there are no regions unfit for crop development in the state of Goiás. The water demand of jatropha, for its full development, is 1,200 mm annual water. Tolerant to drought, jatropha also tolerates rainfall between 360 and 2,400 $\mathrm{mm}$. However, so as not to affect production, ideal cultivation would be in regions where the deficit does not exceed $720 \mathrm{~mm}$ (Yamada \& Sentelhas, 2014).

Temperature is one of the main environmental parameters delimiting environmental conditions for the development of a plant species. In plants, metabolic processes are highly dependent on the temperature of the site where they grow. Environmental temperature exerts a great impact on plant photosynthesis and respiration, since it influences several biochemical reactions related to these two physiological processes (Taiz \& Zeiger, 1998; Beltrão \& De Oliveira, 2008). Extreme air temperatures do not favor the development of certain enzymatic reactions in plants. For this reason, each plant species develops best within a certain air temperature threshold (Bonhomme, 2000). 
One simple way to describe plant growth and its development as a function of air temperature is through degree-days (DD) $\left({ }^{\circ} \mathrm{C}\right.$ day), which is the difference between the average daily temperature and the minimum temperature required by the species, called lower basal temperature (Müller et al., 2009; Pilau, Battisti, Somavilla, \& Schwerz et al., 2011). Degree-days are used to include the effects of air temperature on biological processes as a function of time, on different developmental stages, allowing a rough estimate of the time at which a particular phenological stage will occur (Salazar-Gutierrez, Johnson, Chaves-Cordoba, \& Hoogenboom, 2013).

Most studies on the subject neglect upper basal temperature in the assessment of degree-days since it shows a high value, rarely reached in the field during crop development (Müller et al., 2009). Notwithstanding, some models use this measure for determining degree-days, highlighting the importance of knowledge of both basal temperatures to optimize monitoring strategies, to improve yield and quality, to support selection and breeding programs, and to choose species that are more adapted to the climatic conditions of the growing site (Müller et al., 2009; Martins, Reis, \& Pinheiro, 2012). With temperature values below or above the basal ones, development does not occur.

Several authors have proposed different classes of agroclimatic aptitude for jatropha. Due to the lack of bibliographic records evidencing the estimated value of basal temperatures for the development of jatropha, there is no consensus on the ideal temperature range. Jatropha is a crop valued due to its great importance in the biodiesel production system, which grows largely in the country. In view of this, and since temperature is an intrinsic development factor, this work determined the lower and upper basal temperature of Jatropha curcas L. Furthermore, we verified the relationship between thermal sum and plant development under different water regimes, in the climatic conditions of Goiânia, GO, Brazil.

\section{Method}

\subsection{Experimental Site}

The study was conducted in an experimental area of the Agronomy School of the Federal University of Goiás (EA-UFG), Goiânia, GO (16 $\left.35^{\prime} 44.22^{\prime \prime} \mathrm{S}, 49^{\circ} 16^{\prime} 44.40^{\prime \prime} \mathrm{W} ; 722 \mathrm{~m}\right)$. According to the climatic classification of Köppen, the climate of the region is type Aw (tropical wet, with dry winter), with annual average temperature, relative humidity and rainfall of $23{ }^{\circ} \mathrm{C}, 70 \%$ and $1,498 \mathrm{~mm}$, respectively (Silva, Heinemann, Paz, \& Amorim 2014).

In the mentioned area, 768 Jatropha curcas L. plants, spaced $3.0 \mathrm{~m}$ apart and $1.5 \mathrm{~m}$ between rows, were cultivated. From this total, 24 plants were evaluated, twelve of which were irrigated from October 2010 to October 2012, and twelve unirrigated ones.

\subsection{Biometric Measurements}

The growth characteristics of the evaluated plants were: i) plant height-measured using graduated ruler; (ii) crown area-determined from measuring the plant crown lengths in the direction of the planting row and perpendicular to it; (iii) stem diameter-measured at a height of $10 \mathrm{~cm}$ from the soil surface; iv) number of branches in the main stem - by direct counting of the branches observed in the plant. Moreover, seed yield was evaluated in two harvests, one in the 2010/2011 crop season and another in the 2011/2012 crop season, both between February and March.

\subsection{Weather Reports}

The variables minimum air temperature $\left(\mathrm{Tm},{ }^{\circ} \mathrm{C}\right)$, maximum air temperature $\left(\mathrm{TM},{ }^{\circ} \mathrm{C}\right)$, average air temperature $\left(\mathrm{Ta},{ }^{\circ} \mathrm{C}\right)$, relative air humidity $(\mathrm{RH} \%)$, rainfall $(\mathrm{R}, \mathrm{mm})$ and wind speed $\left(\mathrm{W}, \mathrm{m} \mathrm{s}^{-1}\right)$ were obtained at the automatic meteorological station of the Agronomy School of the Federal University of Goiás, located $287 \mathrm{~m}$ from the experimental area.

For the determination of lower basal temperature $\left(\mathrm{Tb},{ }^{\circ} \mathrm{C}\right)$, degree-days were calculated $\left(\mathrm{DD},{ }^{\circ} \mathrm{C}\right.$ day) as described by Arnold (1959) (Equation 1):

$$
D D=\frac{T M+T m}{2}-T b
$$

First, $\mathrm{Tb}$ values were established, which varied from $0^{\circ} \mathrm{C}$ to $20^{\circ} \mathrm{C}$, in $0.5^{\circ} \mathrm{C}$ intervals. Thus, $\mathrm{Tb}$ was determined using different methodologies: i) standard deviation, in degree-days $\left(\mathrm{SD}_{\mathrm{DD}}\right)$; ii) standard deviation, in day (SDday); iii) coefficient of variation, in day (CVday); iv) coefficient of variation, in degree-days $\left(\mathrm{CV}_{\mathrm{DD}}\right.$ ) (Arnold, 1959; Yang, Logan, \& Coffey, 1995). 
In the $\mathrm{SD}_{\mathrm{DD}}$ model, the plant's $\mathrm{Tb}$ is considered to be the resultant of the lowest standard deviation, thus $\mathrm{Tb}$ will be the one in which the sum of degree-days (DD) generates less dispersion (Equation 2):

$$
S D_{D D}=\left[\frac{\sum_{i=1}^{N}\left(D D_{i}-D D_{m}\right)^{2}}{n-1}\right]^{1 / 2}
$$

Where, $\mathrm{DD}_{\mathrm{i}}$ is degree-days accumulated in the ith period using a Tb series, $\mathrm{DD}_{\mathrm{m}}$ is the mean of the degree-days accumulated for all itch periods, and $\mathrm{n}$ is the number of periods.

The SDday model is based on the basal temperatures previously selected in the preceding method, resulting from the lowest standard deviation between the different planting times (Equation 3):

$$
S D d a y=\frac{S D_{D D}}{T m-T a g}
$$

Where, SDday is the standard deviation (day), $\mathrm{SD}_{\mathrm{DD}}$ is the standard deviation (DD) and Tag is the global average air temperature from all observations $\left({ }^{\circ} \mathrm{C}\right)$.

$\mathrm{CV}_{\mathrm{DD}}$ was determined by the relationship between $\mathrm{SD}_{\mathrm{DD}}$ and the accumulated degree-days of all plantings (DDm) (Equation 4). CVday, in turn, was obtained according to SDday and the number of days to reach a certain development stage (Xd) (Equation 5):

$$
\begin{aligned}
& C V_{D D}=\frac{S D_{D D}}{D D m} \times 100 \\
& C V \text { day }=\frac{S D d a y}{X d} \times 100
\end{aligned}
$$

Upper basal temperature (TB) was determined following the same methodology applied for Tb. However, the TB value was found when the standard deviation became constant. For this, temperatures between $20{ }^{\circ} \mathrm{C}$ and $40{ }^{\circ} \mathrm{C}$ were used, varying in $0.5^{\circ} \mathrm{C}$.

After the determination of $\mathrm{Tb}$ and $\mathrm{TB}$, we performed the calculations of degree-days (DD, ${ }^{\circ} \mathrm{C}$ day), estimated by the methodology proposed by Ometto (1981), from the following set of equations:

Case $1, \mathrm{~TB}>\mathrm{TM}>\mathrm{Tm}>\mathrm{Tb}$ :

$$
D D=\frac{T M-T m}{2}+(T m-T b)
$$

Case $2, \mathrm{~TB}>\mathrm{TM}>\mathrm{Tb}>\mathrm{Tm}$ :

$$
D D=\frac{(T M-T b)^{2}}{2(T M-T m)}
$$

Case 3, $\mathrm{TB}>\mathrm{Tb}>\mathrm{TM}>\mathrm{Tm}$ :

$$
D D=\frac{2[(T M-T m)(T m-T b)]+(T M-T m)^{2}-(T M-T B)^{2}}{2(T M-T m)}
$$

Case $4, \mathrm{TM}>\mathrm{TB}>\mathrm{Tm}>\mathrm{Tb}$ :

$$
D D=\frac{1}{2} \frac{(T M-T b)^{2}-(T M-T B)^{2}}{T M-T m}
$$

Degree-day values were added in each of the evaluated stages, vegetative growth and maturity, determining the thermal sum necessary to complete each one of them.

\subsection{Statiscal Analysis}

The values of plant growth and development were correlated to the thermal sum by adjusting logistic and sigmoid equations.

\section{Results and Discussions}

The estimated values of lower basal temperature in the maturity and total cycle were equal to 4.9 and $7.2{ }^{\circ} \mathrm{C}$, respectively (Figure 1), regardless of the estimation method. 

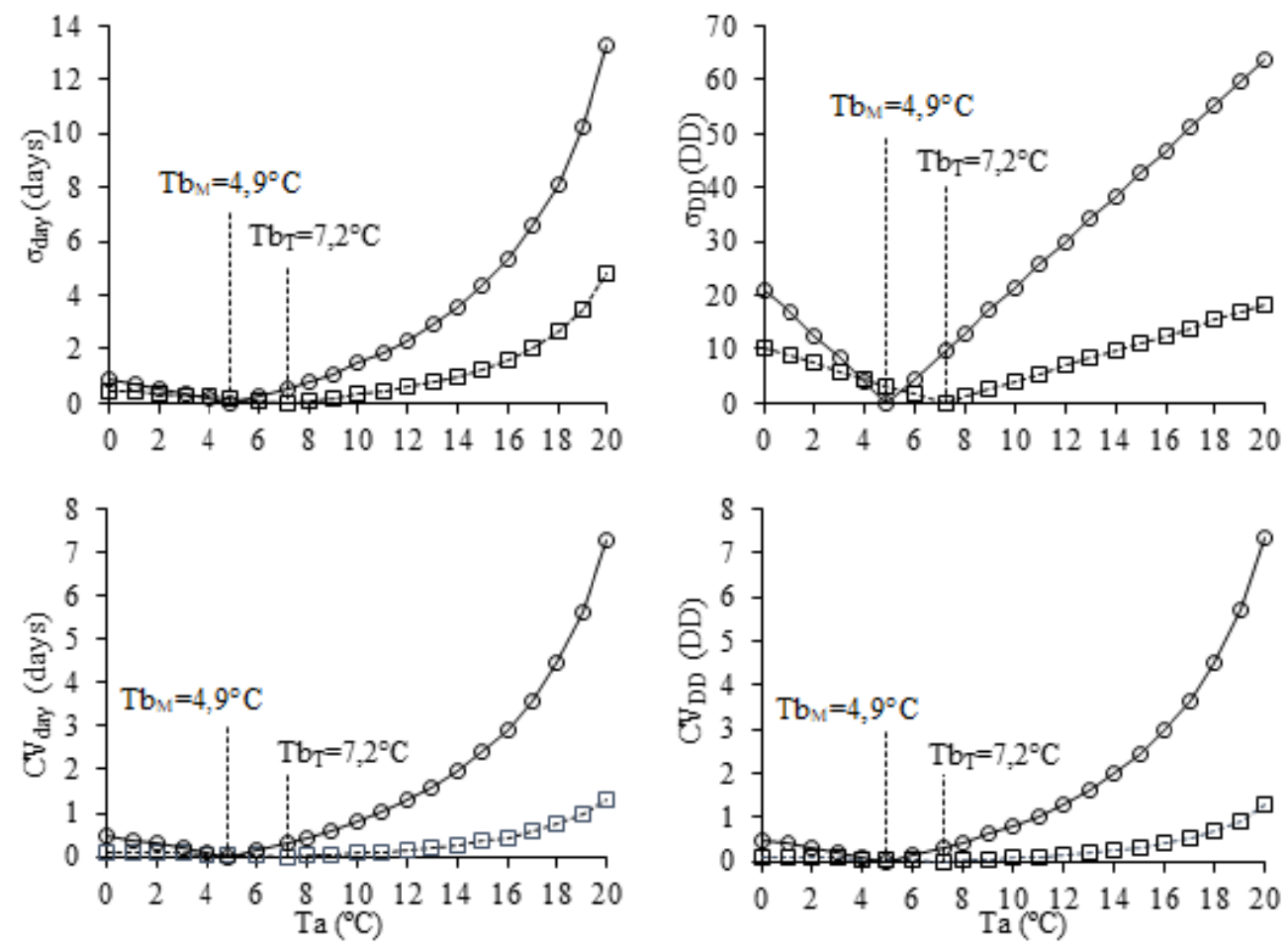

Figure 1. Method of the lowest standard deviation $(\sigma)$ and coefficient of variation $(\mathrm{CV} \%)$ for determination of lower basal temperature $\left(\mathrm{Tb},{ }^{\circ} \mathrm{C}\right)$ regarding maturity $(\mathrm{M}, \circ)$ and total cycle $(\mathrm{T}, \square)$

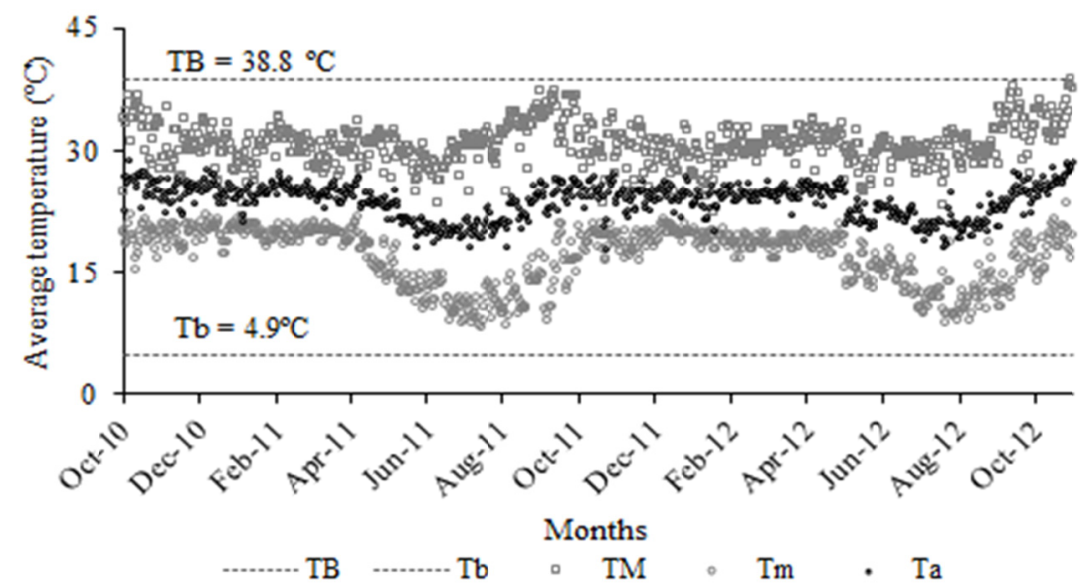

Figure 2. Maximum $\left(\mathrm{TM},{ }^{\circ} \mathrm{C}\right)$, minimum $\left(\mathrm{Tm},{ }^{\circ} \mathrm{C}\right)$ and average air temperature $\left(\mathrm{Ta},{ }^{\circ} \mathrm{C}\right)$; and upper $(\mathrm{TB})$ and lower $(\mathrm{Tb})$ basal temperatures for jatropha

Small differences were detected in the Tb values estimated by the four methods tested, $\mathrm{SD}_{\mathrm{DD}}, \mathrm{SDday}_{\mathrm{C}} \mathrm{CV}_{\mathrm{DD}}$ and CVday (Figure 1). This can be explained by the low variability and high stability of the maximum and minimum temperature data during the studied period, presenting a mean thermal amplitude of $13.85{ }^{\circ} \mathrm{C}\left( \pm 4.4{ }^{\circ} \mathrm{C}\right)$. The mean temperature of the period was $23.78^{\circ} \mathrm{C}\left( \pm 2.1^{\circ} \mathrm{C}\right)$, ranging from 20.12 to $26.43{ }^{\circ} \mathrm{C}$ (Figure 2).

Souza, Silva, Leonel, and Escobedo (2009) sought to establish basal temperatures for fig tree using the same methods and found small differences in deviation values. They explain this equality due to low temperature variability, with mean thermal amplitude of $9.79{ }^{\circ} \mathrm{C}\left( \pm 1.3{ }^{\circ} \mathrm{C}\right)$ and average temperature of $19.65{ }^{\circ} \mathrm{C}\left( \pm 2.4{ }^{\circ} \mathrm{C}\right)$ throughout the study, ranging from 15.09 to $24.49^{\circ} \mathrm{C}$.

Agroclimatic zoning for jatropha shows that average temperatures below $15{ }^{\circ} \mathrm{C}$ correspond to climatic risk, rendering the crop unsuitable for cultivation (Pena et al., 2016; Yamada and Sentelhas 2014). These authors considered thermal zones suitable for jatropha cultivation, or optimum air temperatures, when values were 
between 15 and $28{ }^{\circ} \mathrm{C}$. By concept, the crop presents the highest growth rates with such values. Nonetheless, jatropha plants do not show zero growth when air temperatures below $15{ }^{\circ} \mathrm{C}$ occur, initiating only a reduction of these rates, tending to zero. This makes the value of $7.2{ }^{\circ} \mathrm{C}$ for $\mathrm{Tb}$ (total cycle), found in this study, to be a coherent value.

Jatropha has a wide range of thermal adaptability; however, it has little tolerance to low air temperatures, and its lethal range is between -3 and $4{ }^{\circ} \mathrm{C}$ (Andrade, Caramori, De Souza, Jamil Marur, \& De Arruda Ribeiro, 2008). Jatropha seeds remain vigorous ( $90 \%$ germination) when submitted to temperatures of $10{ }^{\circ} \mathrm{C}$ (Oliveira, Hilst, Da Silva, Sekita, \& dos Santos Dias, 2015).

The values found for upper basal temperature (TB) were 36.8 and $38.8{ }^{\circ} \mathrm{C}$, corresponding to maturity and total cycle, respectively, again with little difference in the methodologies used (Figure 3).
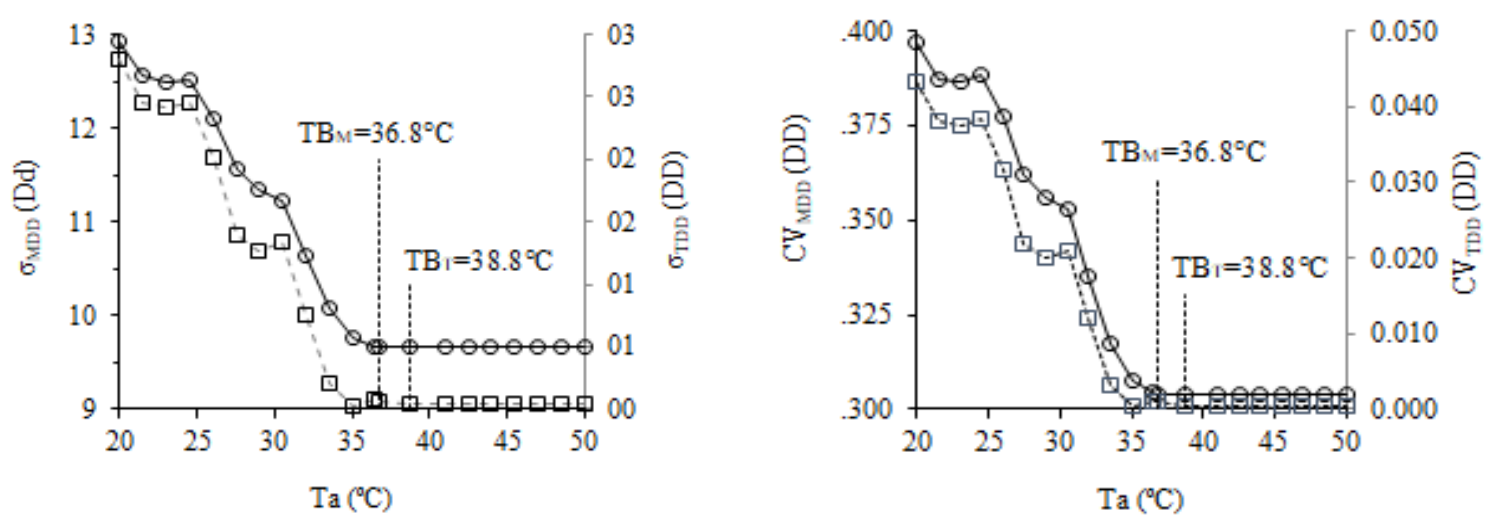

Figure 3. Method of the lowest standard deviation $(\sigma)$ and coefficient of variation $(\mathrm{CV} \%)$ for determination of upper basal temperature $\left(\mathrm{TB},{ }^{\circ} \mathrm{C}\right)$ regarding maturity $(\mathrm{M}, \circ)$ and total cycle $(\mathrm{T}, \square)$

Information on the agrometeorological relations of jatropha is scarce in the literature, especially regarding basal temperatures. Pascuali, Schwanz da Silva, Gonçalves Porto, and Meneghello (2012) verified that the temperature of $40{ }^{\circ} \mathrm{C}$ decreases the percentage of normal seedlings by up to $82 \%$. On the other hand, reports indicate that jatropha seeds exposed to the sun and under temperatures between 33 and $43{ }^{\circ} \mathrm{C}$ have satisfactory rates of germination and vigor (Zonta, E. Araujo, R. Araujo, \& Dias, 2011). High temperature values are evidenced by Yamada and Sentelhas (2014), who found high thermal adaptability for the same crop when performing its agroclimatic zoning. Thus, these studies corroborate the TB values determined in the present study (Figure 3).

The thermal sum accumulated in the maturity stage of jatropha $\left(\mathrm{Tb}=4.9{ }^{\circ} \mathrm{C}\right.$; $\left.\mathrm{TB}=38.8{ }^{\circ} \mathrm{C}\right)$, in the two production cycles evaluated, was 3,271.00 and 2,054.05 DD for non-irrigated system, taking on average 182 days to complete the development stage and conclude fruit ripening, and 2,726.60 and 1,593.35 DD for irrigated system, concluding the cycle with a mean of 151 days. The number of branches was considered as a reference to development (Figure 4). 

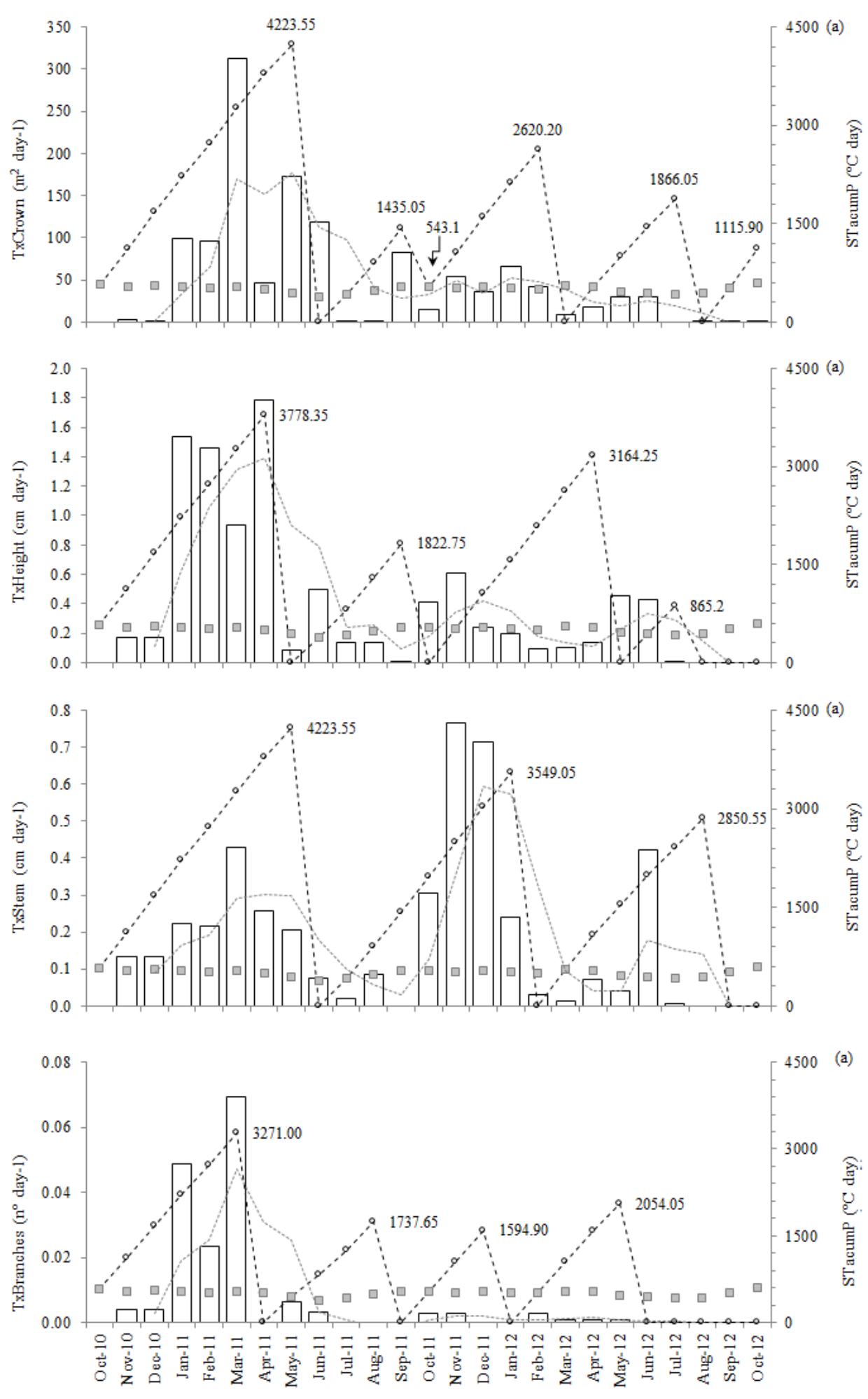

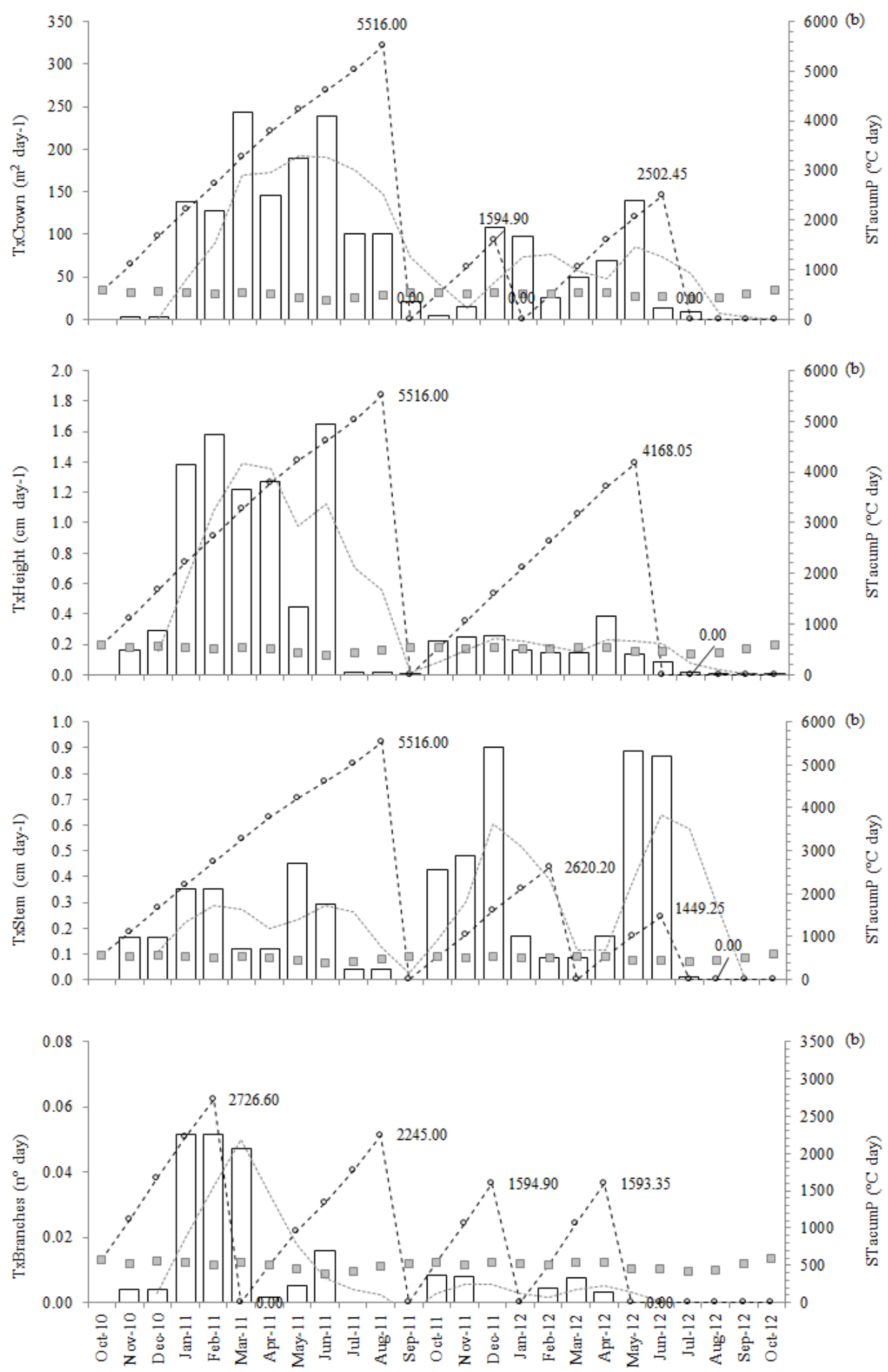

Figure 4. Growth rates: crown area, height, stem and branches (white columns), as a function of time (months-year) and accumulated thermal sum in periods of increasing or constant growth rates (black dashed lines and circles), as well as the monthly thermal sum (gray squares) and the moving average of the growth rates (gray dashed line), for non-irrigated (a) and irrigated (b) treatments

Similar values were found for avocado (Persea americana [Miller]), which is a perennial fruit of climatic adaptability similar to jatropha (Lucchesi, Montenegro, Nova, \& Florencio, 1977). The authors determined a thermal sum for the fruiting/ripening cycle equal to 2,513 DD for the Pollock cultivar, and 3,278 DD for the hybrid cultivar (Antilhana $\times$ Guatemalense). The average temperature observed during the study period was 
$22.6^{\circ} \mathrm{C}$, close to that found in the present study $\left(\mathrm{Ta}=23.7^{\circ} \mathrm{C}\right)$, which may explain this similarity, along with its $\mathrm{Tb}=10^{\circ} \mathrm{C}$.

Non-irrigated plants presented different cumulative degree-day cycles among plant growth factors (Figure 4a). Crown area, height, stem diameter and number of branches showed 12,346.95; 9,630.50; 10,623.15 and 8,657.60 total DD, respectively, for full development. In irrigated treatments, the cumulative cycles were similar to those recorded in non-irrigated treatments (Figure 4b). Crown area, height, stem diameter and number of branches showed 9,613.35; 9,684.05; 9,585.45 and 8,159.85 total DD for stabilizing development. The values highlighted in Figure 4 are observed in Figure 5 as the final mark of a growing and regular increase between the points and trend lines, strongly represented in the cumulative cycles.

The plant growth factor number of branches had four well-defined cumulative cycles for both treatments, irrigated or non-irrigated (Figure 4). These four cumulative cycles are related to the jatropha phenology proposed by Oliveira (2015), who observed a strong occurrence of sprouting, fruiting and maturity between October and April, and dormancy and senescence between April and September.

The plant growth characteristics evaluated presented a high correlation with the average accumulation of thermal sum. Correlations were positive with high coefficient of determination $\left(\mathrm{R}^{2}\right)$ for both factors evaluated (Table 1).
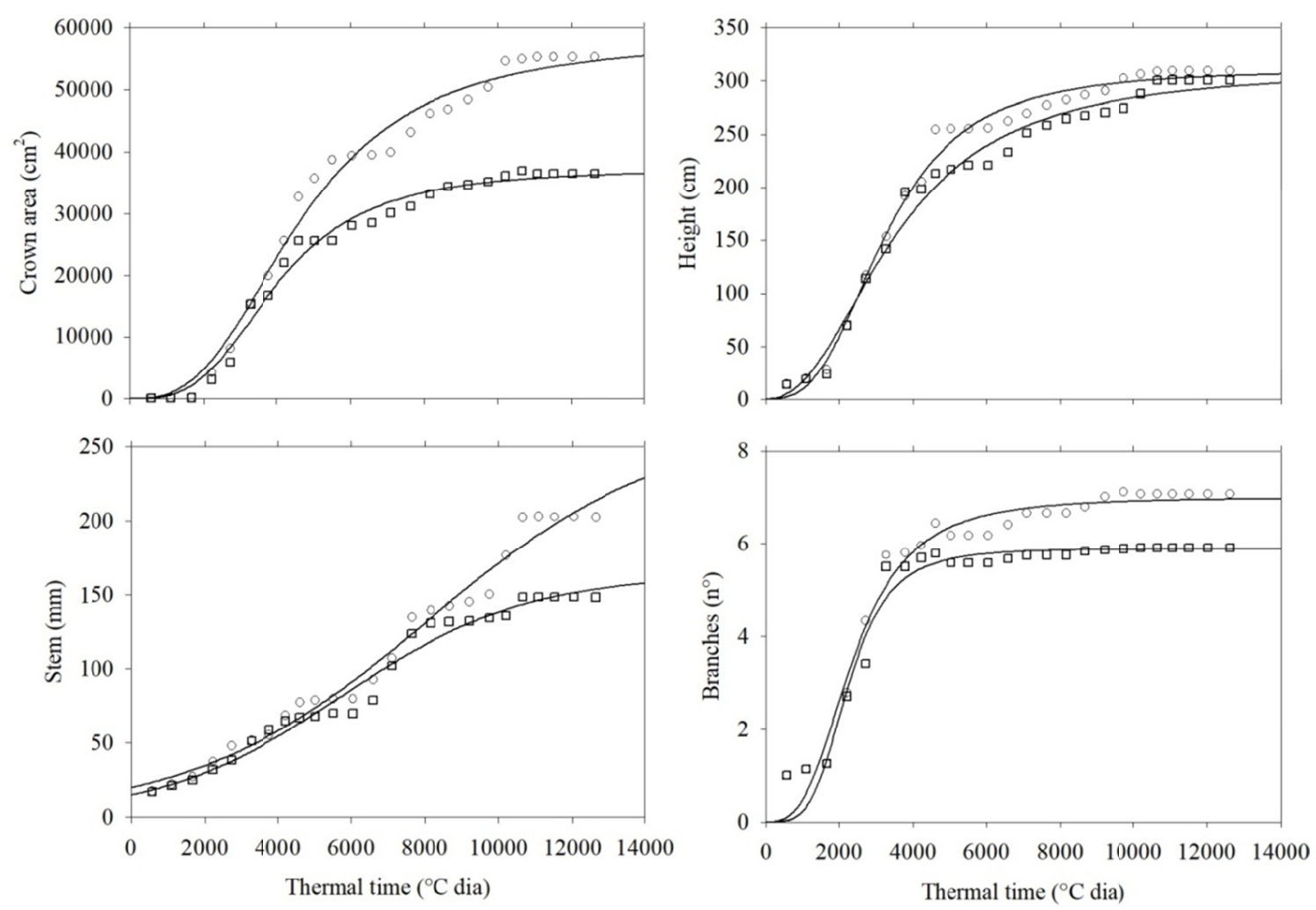

Figure 5. Growth variables of jatropha: crown area, plant height, stem diameter and number of branches for irrigated ( $\odot$ ) and non-irrigated ( $\square$ ) system, as a function of accumulated thermal sum (TS, ${ }^{\circ} \mathrm{C}$ day), as well as the adjustment of logistic equations (full black line) 
Table 1. Logistic and sigmoid equations, with three parameters, adjusted to the jatropha growth data, described by crown area, plant height, stem diameter and number of branches, for irrigated and non-irrigated system, as a function of the accumulated thermal sum $\left(\mathrm{ST},{ }^{\circ} \mathrm{C}\right.$ day)

\begin{tabular}{|c|c|c|}
\hline Equations & Parameters & $\mathbf{R}^{2}$ \\
\hline $\begin{array}{l}\text { Irrigated } \\
\text { If } \mathrm{b}>0, \\
\text { Crown Area }=\frac{a}{1+\left|\frac{x}{x_{0}}\right|^{b}} \\
\text { If } \mathrm{b}<0, \\
\text { Crown Area }=a \cdot \frac{\left|\frac{x}{x_{0}}\right|^{|b|}}{1+\left|\frac{x}{x_{0}}\right|^{|b|}}\end{array}$ & $\begin{array}{l}a=57,953.2940 \\
b=-2.8109 \\
x_{0}=4,665.7600\end{array}$ & 0.9860 \\
\hline $\begin{array}{l}\text { If } \mathrm{b}>0, \\
\text { Plant Height }=\frac{a}{1+\left|\frac{x}{x_{0}}\right|^{b}} \\
\text { If } \mathrm{b}<0, \\
\text { Plant Height }=a \cdot \frac{\left|\frac{x}{x_{0}}\right|^{|b|}}{1+\left|\frac{x}{x_{0}}\right|^{|b|}}\end{array}$ & $\begin{array}{l}\mathrm{a}=310.7040 \\
\mathrm{~b}=2.9449 \\
\mathrm{x}_{0}=3,264.4700\end{array}$ & 0.9906 \\
\hline Stem Diameter $=\frac{a}{1+\exp \left[-1\left(\frac{x-x_{0}}{b}\right)\right]}$ & $\begin{array}{l}\mathrm{a}=265.7473 \\
\mathrm{~b}=3,216.0321 \\
\mathrm{x}_{0}=8,092.0300\end{array}$ & 0.9814 \\
\hline $\begin{array}{l}\text { If } \mathrm{b}>0 \text {, } \\
\text { If } \mathrm{b}<0, \\
\text { Number of Branches }=\frac{\left|\frac{x}{x_{0}}\right|^{|b|}}{1+\left|\frac{x}{x_{0}}\right|^{|b|}}\end{array}$ & $\begin{array}{l}a=7.0048 \\
b=-3.0703 \\
x_{0}=2,378.5900\end{array}$ & 0.9713 \\
\hline $\begin{array}{l}\text { Non-irrigated } \\
\text { If } \mathrm{b}>0 \text {, } \\
\text { Crown Area }=\frac{a}{1+\left|\frac{x}{x_{0}}\right|^{b}} \\
\text { If } \mathrm{b}<0 \text {, } \\
\text { Crown Area }=a \cdot \frac{\left|\frac{x}{x_{0}}\right|^{|b|}}{1+\left|\frac{x}{x_{0}}\right|^{|b|}}\end{array}$ & $\begin{array}{l}a=37,170.4475 \\
b=-3.1564 \\
x_{0}=4,011.0600\end{array}$ & 0.9871 \\
\hline $\begin{array}{l}\text { If } \mathrm{b}>0 \text {, } \\
\text { If } \mathrm{b}<0 \text {, } \\
\text { Plant Height }=a \cdot \frac{\left|\frac{x}{x_{0}}\right|^{|b|}}{1+\left|\frac{x}{x_{0}}\right|^{|b|}}\end{array}$ & $\begin{array}{l}a=311.1390 \\
b=-2.2818 \\
x_{0}=3,545.7100\end{array}$ & 0.9839 \\
\hline Stem Diameter $=\frac{a}{1+\exp \left[-1\left(\frac{x-x_{0}}{b}\right)\right]}$ & $\begin{array}{l}a=163.0896 \\
b=2,489.4524 \\
x_{0}=5,721.0780\end{array}$ & 0.9766 \\
\hline $\begin{array}{l}\text { If } \mathrm{b}>0 \text {, } \\
\text { If } \mathrm{b}<0 \text {, } \\
\text { Number of Branches }=\frac{a}{1+\left|\frac{x}{x_{0}}\right|^{b}} \\
1+\left|\frac{x}{x_{0}}\right|^{|b|} \\
\left.1 \frac{x}{x_{0}}\right|^{|b|}\end{array}$ & $\begin{array}{l}a=5.8899 \\
b=-4.0498 \\
x_{0}=2,254.4000\end{array}$ & 0.9575 \\
\hline
\end{tabular}


The values of the coefficients "a" (Table 1) of the logistic equations adjusted to the data of the development characteristics of the evaluated plant indicate that there was effect of degree-day accumulation on these characteristics in the different treatments. It was also possible to observe a substantially higher development between irrigated and non-irrigated treatments (Figure 5), as can be seen in the coefficient "a" of the logistic equations. The crown area, stem diameter and number of branches of irrigated plants averaged $33.9 \%, 26.9 \%$ and $16.5 \%$ higher than those of non-irrigated plants. This increase can be explained by the water deficit that probably occurred. The climatic water balance (Figure 7) confirms that the treatment with irrigation presented a higher deficit of available water during the drought months in the study region, from April to October.

Regarding the months with water deficit, the deficit in the cumulative cycles of the number of branches affected growth rates (Figure 4). Irrigated treatments showed an accumulation of 2,245.00 DD, against the 1,737.65 DD accumulation of non-irrigated treatments. Other growth rates had a higher cumulative effect during these months, mainly in the 1st cycle, 5,516.00 DD for crown area, height and stem diameter. The response of treatments to the degree-days accumulated from October/2010 to September/2011 highlights the sensitivity of the crop to the degree-days, and the effect on its accumulation when exposed to extreme water deficit situations.

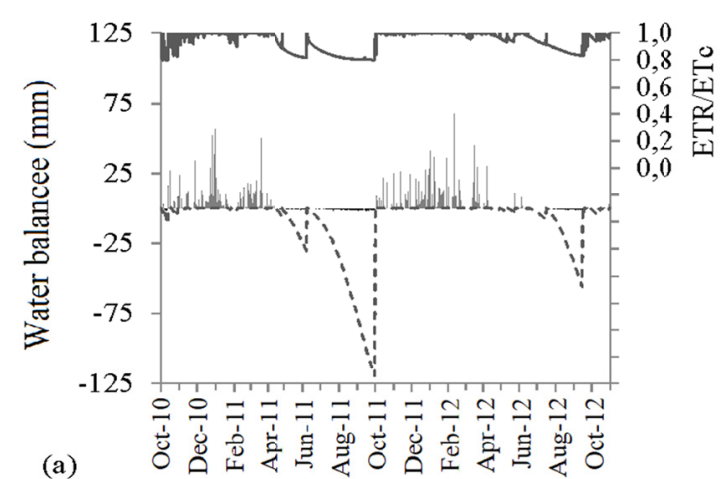

SUR

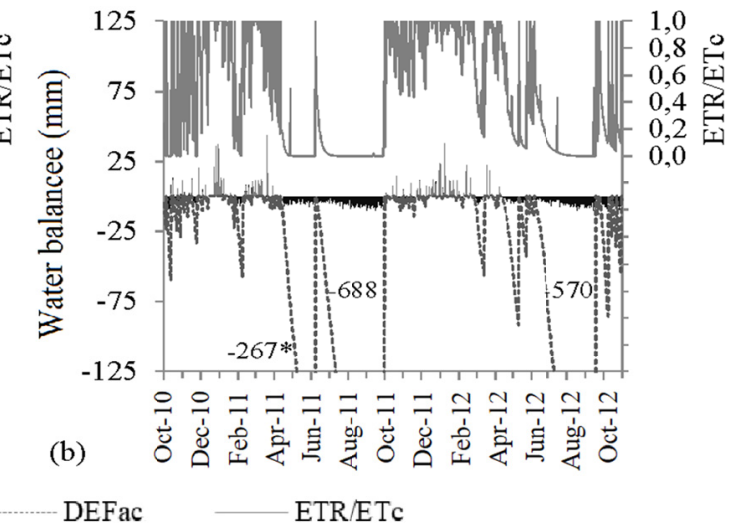

Figure 6. Daily sequential water balance for jatropha crop: daily water surplus (SUR, mm), daily water deficit (DEF, $\mathrm{mm}$ ), accumulated deficit (DEFac, $\mathrm{mm}$ ) and relative evapotranspiration (ETR/ETc); for the two years of cultivation in irrigated (a) and non-irrigated (b) system. *Maximum values of DEFac in the periods: 04/12/11 to $06 / 07 / 11 ; 06 / 09 / 11$ to $09 / 30 / 11 ; 06 / 06 / 12$ to $09 / 17 / 12$

\section{Conclusion}

Lower basal temperatures for jatropha in the maturity and total cycle stages were $4.9^{\circ} \mathrm{C}$ and $7.2{ }^{\circ} \mathrm{C}$, respectively. Upper basal temperatures were $36.8^{\circ} \mathrm{C}$ and $38.8^{\circ} \mathrm{C}$, respectively, for the maturity and total cycle stages.

About 10,314.55 DD $( \pm 1574.73)$ must be available for the complete development of rainfed jatropha, and about 9260.67 DD ( \pm 735.06$)$ for jatropha cultivated in irrigated system.

For fruit development, the irrigated system requires between 3271.00 and $2054.05{ }^{\circ} \mathrm{C}$, and the non-irrigated system requires between 2245.00 and $1539.35^{\circ} \mathrm{C}$.

Plant growth rates were satisfactorily adjusted to the accumulated degree-days, with determination coefficients higher than $95 \%$. Therefore, these rates are highly sensitive to degree-day accumulation.

\section{References}

Andrade, G. A., Caramori, P. H., de Souza, F. S., Jamil Marur, C., \& de Arruda Ribeiro, A. M. (2008). Temperatura mínima letal para plantas jovens de pinhão-manso. Bragantia, 67(3), 799-803. https://doi.org/ $10.1590 / \mathrm{S} 0006-87052008000300031$

Arnold, C. Y. (1959). The determination and significance of the base temperature in a linear heat unit system. Proceedings America Society for Horticulture Science, 74(4), 430-445.

Arruda, F. P., Beltrão, N. E. D. M., De Andrade, A. P., Pereira, W. E., \& Severino, L. S. (2004). Cultivo de pinhão manso (Jatropha curca L.) como alternativa para o semi-árido nordestino. Revista Brasileira de Oleaginosas e Fibrosas, 8(1), 789-799. 
Beltrão, N. D. M., \& De Oliveira, M. I. P. (2008). Efeitos do clima no metabolismo vegetal: Mamona. Campina Grande, PB: Embrapa Algodão.

Bonhomme, R. (2000). Bases and limits to using 'degree.day’units. European Journal of Agronomy, 13(1), 1-10. https://doi.org/10.1016/S1161-0301(00)00058-7

Freitas, R. G., Missio, R. F., Matos, F. S., Resende, M. D. V., \& Dias, L. A. S. (2011). Genetic evaluation of Jatropha curcas: An important oilseed for biodiesel production. Genetics and Molecular Research, 10(3), 1490-1498. https://doi.org/10.4238/vol10-3gmr1146

Lucchesi, A. A., Montenegro, H. W., Nova, N. A. V., \& Florencio, A. C. (1977). Estimativa de graus-dia acumulados no ciclo de frutificação de cultivares de abacateiros (Persea americana, Miller). Anais da Escola Superior de Agricultura Luiz de Queiroz, 34, 317-325. https://doi.org/10.1590/S0071-127619770 00100022

Martins, F. B., Reis, D. D. F., \& Pinheiro, M. V. P. (2012). Temperatura base e filocrono em duas cultivares de oliveira. Ciência Rural, 42(11), 1975-1981. https://doi.org/10.1590/S0103-84782012001100011

Müller, L., Manfron, P. A., Medeiros, S. L. P., Streck, N. A., Mittelmman, A., Dourado Neto, D., \& Morais, K. P. (2009). Temperatura base inferior e estacionalidade de produção de genótipos diplóides e tetraplóides de azevém. Ciência Rural, 39(5), 1343-1348. https://doi.org/10.1590/S0103-84782009005000098

Oliveira, G. L., Hilst, P. C., da Silva, L. J., Sekita, M. C., \& dos Santos Dias, D. C. F. (2015). Teste de frio para avaliação do potencial fisiológico de sementes de pinhão manso (Jatropha curcas L.). Bioscience Journal, 31(2), 509-517. https://doi.org/10.14393/BJ-v31n2a2015-22397

Oliveira, R. J. P. D. (2015). Fenologia, manejo e desempenho agronômico de genótipos de pinhão-manso em Pelotas-RS (Doctoral these, Universidade Federal de Pelotas, Pelotas, Brazil). Retrieved from http://repositorio.ufpel.edu.br

Ometto, J. (1981). Bioclimatología Vegetal (1st ed.). Sao Paulo, SP: Editorial Agronómica Ceres Ltda.

Pascuali, L. C., Schwanz da Silva, F., Gonçalves Porto, A., da Silva Filho, A., \& Meneghello, G. E. (2012). Germinação de sementes de pinhão manso em diferentes temperaturas, luz e substratos. Semina: Ciências Agrárias, 33(4), 1435-1440. https://doi.org/10.5433/1679-0359.2012v33n4p1435

Pena, D. S., Evangelista, A. W. P., \& Casaroli, J. A. J. (2016). Agroclimatic zoning for jatropha crop (Jatropha curcas L.) in the State of Goiás. Acta Scientiarum. Agronomy, 38(3), 329-335. https://doi.org/10.4025/ actasciagron.v38i3.28224

Pilau, F. G., Battisti, R., Somavilla, L., \& Schwerz, L. (2011). Temperatura basal, duração do ciclo e constante térmica para a cultura do crambe. Bragantia, 70(4), 958-964. https://doi.org/10.1590/S0006-870520110 00400032

Salazar-Gutierrez, M. R., Johnson, J., Chaves-Cordoba, B., \& Hoogenboom, G. (2013). Relationship of base temperature to development of winter wheat. International Journal of Plant Production, 7(4), 741-762.

Silva, S. D., Heinemann, A., Paz, R. L. F., \& Amorim, A. D. O. (2012). Informações meteorológicas para pesquisa e planejamento agrícola, referentes ao Município de Santo Antônio de Goiás, GO. Santo Antônio de Goiás, GO: Embrapa Arroz e Feijão.

Souza, A. P. D., Silva, A. C. D., Leonel, S., \& Escobedo, J. F. (2009). Temperaturas basais e soma térmica para a figueira podada em diferentes épocas. Revista Brasileira de Fruticultura, 31(2), 314-322. https://doi.org/ 10.1590/S0100-29452009000200005

Taiz, L., \& Zeiger, E. (1998). Cell walls: Structure, biogenesis, and expansion. Plant Physiology (pp. 409-443). Sinauer Associates, Sunderland, MA.

Yamada, E. S., \& Sentelhas, P. C. (2014). Agro-climatic zoning of Jatropha curcas as a subside for crop planning and implementation in Brazil. International Journal of Biometeorology, 58(9), 1995-2010. https://doi.org/ 10.1007/s00484-014-0803-y

Yang, S., Logan, J., \& Coffey, D. L. (1995). Mathematical formulae for calculating the base temperature for growing degree days. Agricultural and Forest Meteorology, 74(1-2), 61-74. https://doi.org/10.1016/ 0168-1923(94)02185-M 
Zonta, J. B., Araujo, E. F., Araujo, R. F., \& Dias, S. (2011). Diferentes tipos de secagem: Efeitos na qualidade fisiológica de sementes de pinhão manso. Revista Brasileira de Sementes, 33(4), 721-731. https://doi.org/ 10.1590/S0101-31222011000400014

\section{Copyrights}

Copyright for this article is retained by the author(s), with first publication rights granted to the journal.

This is an open-access article distributed under the terms and conditions of the Creative Commons Attribution license (http://creativecommons.org/licenses/by/4.0/). 